\title{
Empowering Cultural Heritage in Penataran Sima Siladan Temple for the Development of the Taman Bali Tourism Village, Bangli
}

\author{
Anak Agung Gede Raka, Anak Agung Rai Sita Laksmi, Anak Agung Gede, Oka Wisnumurti, \\ I Made Mardika \\ \{dapurpoleng@gmail.com\}
}

Public Administration Study Program, Postgraduate, Warmadewa University

\begin{abstract}
Penataran Sima Siladan Temple is located in Taman Bali Village, Bangli Regency. This temple consists of diverse cultural heritage in form of ancient relics such as primitive statues, Barong Landung, temple sites, and traditions of Barong Landung. However, the potential of cultural heritage owned by the community has not been properly empowered. Therefore, this research aims to empower the community by developing the Penataran Siladan Temple in order to support Taman Bali Village, Bangli as a tourism area. Data were obtained by carrying out inventory activities in the Temple, as well as by holding lectures on penyungsung, which forms a Siladan pesraman (Hindu special education institution) used to conduct English training for the younger generation. The results of PKM activities cover 3 fields, namely the inventory of cultural heritage in the Penataran Siladan Temple, carrying out lectures to the temple penyungsung, as well as the formation of Siladan pesraman and the implementation of English training for Siladan elementary school children. The result showed that the PKM supports Cultural Heritage development of the Taman Bali Tourism Village in Bangli, with the publication of a national seminar paper in the CSJ journal.
\end{abstract}

Keywords: empowerment, cultural heritage, tourist village

\section{Pendahuluan}

Desa Tamanbali merupakan salah satu dari 5 Desa yang ada di kecamatan Bangli, yang terletak $5 \mathrm{~km}$ ke arah selatan kota Kecamatan. Luas wilayah Desa Tamanbali adalah 657 hektar, dengan batas-batas: di sebelah utara Kelurahan Bebalang Kabupaten Bangli, di sebelah timur Desa Nyalian Kabupaten Klungkung, di sebelah selatan Desa Sidan Kabupaten Gianyar, dan di sebelah barat Desa Bunutin Kabupaten Bangli. Jumlah penduduk Tamanbali adalah 6769 orang, terdiri atas laki-laki 3253: jiwa, perempuan: 3516 Jiwa, jumlah kepala keluarga (KK): 1850. Mata pencaharian penduduk sebagian besar sebagai petani, peternak, pengerajin disamping ada juga sebagai PNS, TNI, POLRI dan pekerjaan lainnya.

Secara administratif Desa Taman Bali mewilayahi 10 dusun/lingkungan terdiri atas: Dusun Dadia, Dusun Gaga, Dusun Guliang Kangin, Dusan Jelekungkang, Dusun Kuning, Dusun sidawa, Dusun Siladan, Dusun Pande, Dusun Teruna, dan Dusun Umanyar. Seperti halnya 
desa-desa di Bali, Desa Taman Bali terdiri atas beberapa desa adat/desa pekraman. Desa Pekraman yang terdapat di Desa Taman Bali diantaranya, Desa Pekraman Guliang Kangin, Desa Pekraman Jelekungkang, dan Desa Pekraman Siladan.

Desa Tamanbali termasuk ke dalam Zona Pengembangan Pariwisata di Kabupaten Bangli. Di Desa ini terdapat sejumlah DTW yang menjadi unggulan Bangli, diantaranya: Taman Narmada Baliraja, Air terjun Dedari, Air terjun Kuning, Desa Wisata Guliang Kangin, dan Pura Tirta Arum. Taman Narmada Bali Raja telah ditetapkan sebagai DTW berdasarkan Perda No. 9 Tahun 2013. Desa Wisata Guliang Kangin dikembangkan sebagai Destinasi Wisata berbasis alam dan budaya dengan Peraturan Bupati Bangli Nomor 16 Tahun 2014, sedangkan Air Terjun di Banjar Kuning ditetapkan sebagai obyek wisata khusus air terjun.

Kendatipun beberapa potensi desa telah dikembangkan menjadi DTW, akan tetapi belum dapat menjangkau seluruh dusun atau Desa Pekraman yang ada di Desa Taman Bali. Potensi seni budaya yang ada di wilayah desa penting untuk dikembangkan guna menunjang Tamanbali sebagai desa wisata terintegrasi. Satu diantaranya adalah potensi pariwisata yang ada di Desa Pekraman Siladan. Di Desa Pekraman Siladan terdapat warisan budaya Pura Penataran Sima Siladan maupun unsur seni budayaa lainnya yang dapat dikembangkan sebagai pendukung Desa Wisata di Desa Taman Bali Bangli. Pura Penataran Sima Siladan memiliki potensi warisan budaya yang cukup beragam. Warisan budaya yang ada terdiri atas tinggalan purbakala berupa arca primitif, Barong Landung, situs pura, dan tradisi seni budaya Barong Landung. Potensi warisan budaya yang dimiliki masyarakat ini belum diberdayakan dalam rangka pengembangan Desa Wisata Taman Bali Bangli. Oleh karena itu, Pengabdian Kepada Masyarakat (PKM) Program Studi Magister Administrasi Publik Pascasarjana Unwar memandang perlu melakukan aksi pemberdayaan kepada masyarakat di Desa Pekraman Siladan Sasaran PKM di Desa Pekraman Siladan.adalah warisan budaya di Pura Penataran Sima Siladan, serta warga masyarakat penyungsung pura. Untuk mencapai sasaran tersebut, yang dijadikan mitra PKM ialah Pemangku pura dan Bendesa Desa Pekraman Siladan. Tiga permasalahan mitra yang hendak dicarikan solusinya, meliputi: (1) kurang diketahuinya keberadaan warisan budaya di Pura Penataran Sima Siladan, dan (2) tidak dipahaminya makna warisan budaya tersebut, (3) kurangnya ketrampilan generasi budaya dalam seni budaya Bali. Dengan demikian, program PKM ini bertujuan melakukan pemberdayaan masyarakat dengan mengembangkan potensi warisan budaya di Pura Penataran Siladan untuk menunjang Desa Taman Bali Bangli sebagai Desa Wisata.

\section{Metode Pelaksanaan}

Metode pelaksanaan PKM di Desa Pekraman Siladan merupakan program pemberdayaan kelompok masyarakat melalui tiga model kegiatan. Pertama, melakukan inventarisasi warisan budaya di Pura Penataran Siladan. Kedua, mengadakan ceramah atau penyuluhan kepada penyungsung pura tentang peran warisan budaya sebagai daya Tarik wisata. Ketiga, membentuk pesraman Siladan untuk melakukan pelatihan Bahasa Inggris dan seni budaya Bali kepada anak-anak sekolah di Desa Pekraman Siladan.

Inventarisasi warisan budaya dilakukan dengan mengadakan pendataan bentuk-bentuk tinggalan arkeologi yang ada di Pura, memeriksa kondisi fisik tinggalan, mendeskripsi, dan menganalisis secara arkeologis warisan budaya yang dimiliki. Metode arkeologi yang diterapkan melalui tiga tahapan baik menyangkut bentuk (space/form), pertanggalan relatif (time), analisis fungsi (fungsional) dan menjelaskan/menafsirkan maknanya (meaning). 
Hasil inventarisasi dan deskripsi tinggalan warisan budaya tersebut sebagai landasan tahap kedua yaitu melakukan penyuluhan tentang makna warisan budaya di Pura Penataran Sima Siladan bagi masyarakat penyungsung. Metode yang digunakan adalah metode ceramah yakni dengan menjelaskan makna tinggalan budaya yang ada serta kaitannya dengan Petapakan Barong Landung yang ada. Dengan pemberian ceramah kepada penyungsung pura diharapkan masyarakat memahami,menyadari, dan tumbuh rasa bangga terhadap warisan budaya yang sekaligus mampu menjaga / melestarikan warisan yang dimiliki.

Guna meningkatkan ketrampilan generasi muda dalam bidang komunikasi dengan bahasa Inggris, bahasa daerah Bali dan seni budaya Bali, maka perlu dibentuk pesraman. Pesraman Siladan dapat dipandang sebagai wadah generasi muda meningkatkan ketrampilannya di bidang bahasa Asing dan seni budaya. Metode pembelajaran yang digunakan adalah dengan pendampingan penyediaan tenaga pendidik bahasa Inggris dan seni budaya Bali dengan teknik pengajaran "belajar sambil bermain".

\section{Hasil Dan Pembahasan}

Secara umum bentuk kegiatan pengabdian yang dilaksanakan oleh Tim Pelaksana PKM di Desa pekraman Siladan dapat dibagi tiga, yaitu: (1) Inventarisasi Warisan Budaya, (2) Penyuluhan Warisan Budaya, dan (3) Pembentukan dan Pelaksanaan Pesraman.

Inventarisasi warisan budaya di Pura Penataran Sima Siladan dilaksanakan selama 3 hari yakni mulai tanggal 10 sampai dengan 12 September 2019. Dalam inventarisasi ini dilakukan pengukuran, pencatatan, dan pemotretan terhadap bentuk-bentuk warisan budaya yang terdapat di Pura Penataran Sima Siladan. Selain itu, juga dilaksanakan perekaman data melalui wawancara mendalam kepada pemangku pura maupun tokoh-tokoh masyarakat Siladan yang mengetahui keberadaan warisan budaya di Pura Penataran Sima Siladan.

Penyuluhan tentang arti penting warisan budaya di Pura Penataran Sima Siladan dilaksanakan pada 15 September 2019 bertepatan dengan hari purnama (bulan penuh). Sebelum penyuluhan dilaksanakan didahului dengan sembahyang bersama tim PKM dengan para penyanggra pura yang sekaligus sebagai peserta ceramah. Model ceramah sengaja dirancang secara dialogis untuk memberikan kesempatan peserta berperan aktif dalam kegiatan penyuluhan tersebut.

Pembentukan Pesraman dan sekaligus pelaksanaan peresmian pesraman dilaksanakan pada tanggal 20 September 2019. Pembentukan pesraman ditandai dengan penandatangan SK pembentukan pesraman oleh Bendesa Desa Pekraman. Pelaksanaan pesraman dibuka secara resmi oleh wakil kepala Desa Taman Bali. Kegiatan Pesraman dilaksanakan tiap minggu pada setiap hari sabtu atau minggu. Peserta Pesraman adalah anak-anak SD dan SMP yang ada di Desa Pekraman Siladan. Sebagai Pembina atau pemberi pelatihan adalah guru bahasa Inggris dan Bahasa Bali yang didampingi oleh Tim pelaksana PKM. Pelaksanaan PKM di Desa Pekraman Siladan menghasilkan tiga wujud program yaitu inventori warisan budaya, pemahaman arti penting warisan budaya, dan pelaksanaan pesraman kepada anaka-anak SD/SMP dari Desa Pekraman Siladan. Terkait dengan inventarisasi warisan budaya yang ada di Pura Penataran Sima Siladan berhasil diidentifikasi tiga variasi bentuk warisan budaya yaitu arca primitive, barong landung dan seni pertunjukan barong landung. Terdapat 6 buah Arca primitive di Pura Penataran sima Siladan yang menunjukkan karakter tradisi megalitik (pra Hindu).Stile arca tergolong arca sederhana yang menonjolkan alat kelamin maupun kedok 
muka. Arca sejenis ini merupakan bentuk arca dari Jaman Tradisi Megalitikum yang kental dengan pemujaan roh leluhur serta berhubungan dengan kesuburan.

Ternyata, arca primitive yang berhubungan dengan kesuburan amat erat kaitannya dengan keberadaan Barong Landung di Pura ini. Barong Landung sebagai tradisi seni akulturasi Bali China merupakan media persembahan untuk memperoleh anugerah kesejahtraan dan keselamatan (kesuburan). Seni Arca Barong Landung mempunyai peran sebagai seni pertunjukan menari mengelilingi desa pada hari-hari tentu dalam upaya menjaga (melindungi) masyarakat dari gangungan berbagai penyakit (penolak bala). Terdapat jalinan erat antara arca primitive, barong landung dan tradisi ngelawang mengelilingi desa sebagai bagian dari budaya spiritual masyarakat Siladan.

Melalui penyuluhan kepada penyungsung pura akan arti penting bentuk-bentuk warisan budaya yang ada telah mampu menggugah kesadaran masyarakat untuk menjaga dan melestarikan warisan budaya tersebut. Masyarakat yang sebelumnya kurang paham akan arti penting bentuk-bentuk warisan budaya yang dimiliki menjadi mengerti dan menumbuhkan keyakinan diri untuk menjaga, melestarikan dan memfungsikan warisan tersebut sebagai bagian dari daya Tarik wisata. Pembentukan dan pelaksanaan pesraman di Siladan telah dapat dijadikan wadah bagi generasi muda untuk meningkatkan ketrampilan baik dalam bidang komunikasi bahasa Inggris praktis, bahasa Bali, maupun melestarikan seni budaya Bali. Sebelumnya, mereka hanya memperoleh pendidikan formal di bangku sekolah, kini anak-anak SD/SMP di Desa Pekraman Siladan mendapatkan tambahan pengetahuan dan ketrampilan babasa asing, bahasa daerah, dan Seni budaya Bali.

\section{Kesimpulan}

Kegiatan PKM di Desa Pekraman Siladan telah berhasil dilaksanakan sesuai rencana. Ada tiga program yang dapat diwujudkan yaitu:

(1) teriventarisasinya warisan budaya di Pura Penataran Siladan,

(2) terlaksananya ceramah kepada penyungsung pura, dan dipahaminya arti penting warisan budaya yang dapat dimanfaatkan sebagai daya tarik wisata desa,

(3) terbentuknya pesraman Siladan dan telah dilaksanakannya pelatihan Bahasa Inggris maupun seni budaya Bali kepada anak-anak SD/SMP dari Desa Pekraman Siladan.

\section{References}

[1] Stutterheim, W.F. 1929. Oudheiden van Bali, terjemahan bebas A.A.Made Tjakra,Tp.

[2] Kempers, A.J Bernet. 1960. Bali Purbakala: Petunjuk Tentang Peninggalan Purbakala di Bali. Djakarta: Penerbit "Ichtiar".

[3] Sutaba, I Made. 1980. Prasejarah Bali. Denpasar: CV. Kayumas

[4] Satrio, A.Junus. 2012. "Perlindungan Warisan Budaya Daerah Menurut Undang- Undang Cagar Budaya", dalam Arkeologi Untuk Publik. Jakarta: Ikatan Ahli Arkeologi Indonesia.

[5] Wirawan, A.A. Bagus. 2008. Pura Dasar dan Sweca Linggarsa Pura. Kabupaten Klugkung: Pura Dasar Gelgel.

[6] Kementeriaan Kebudayaan dan Pariwisata Direktorat Jenderal Sejarah dan Purbakala. 2010. Undang-Undang Republik Idonesia Nomor 11 Tahun 2010 Tentang Cagar Budaya.

[7] Razak, Muhamad.1983. Konservasi Koleksi Perunggu. Jakarta: Departemen Pendidikan dan Kebudayaan Direktorat Jendral Kebudayaan, Museum Nasional. 
[8] Mardika, I Made, A.A.G. Oka Wisnumurti, A.A.R. SitaLasmi. 2018.Dinamika Relasi Kuasa dan Kearifan Lokal pada Warisan Budaya Pura Dasar Buana Gelgel. Laporan Penelitian. Universitas Warmadewa Denpasar.

[9] Raka, A.A.G., I Made Mardika dan I Wayan Wesna Astara. 2016. “.Pengelolaan Warisan Budaya Berbasis Desa Adat di Desa Pejeng, Tampak Siring, Gianyar”. Proseding Seminar Nasional Hasil Penelitian dan Pengabdian Masyarakat dengan tema Inovasi Ipteks Perguruan Tinggi untuk Meningkatkan Kesejahtraan Masyarakat, tanggal 29-30 Agustus 2016 di Fave Hotel, Tohpati Bali

[10] Sudemen, Ida Bagus; Anak Agung Bagus Wirawan; Wayan Dunia dan I Made Kanta. 1983. Sejarah Klungkung : dari Semara Pura Sampai Puputan. Cetakan Kedua. Pemerintah Kabupaten Daerah Tingkat II Klungkung.

[11] Profil Desa Taman Bali Bangli diakses dalam https://tamanbali.desa.id/opensid/index.php/first 